\title{
New evidence concerning the thermal history of Devonian and Carboniferous rocks in the South Portuguese Zone
}

\author{
PAULO FERNANDES ${ }^{1 *}$, JENNIFER A. MUSGRAVE², GEOFF CLAYTON ${ }^{2}$, ZÉLIA PEREIRA ${ }^{3}$, JOSÉ \\ TOMÁS OLIVEIRA ${ }^{4}$, ROBBIE GOODHUE ${ }^{2} \&$ BRUNO RODRIGUES $^{1}$ \\ ${ }^{1}$ Universidade do Algarve, Centro de Investigação Marinha e Ambiental, Campus de Gambelas, 8005-139 Faro, Portugal \\ ${ }^{2}$ Department of Geology, Trinity College, University of Dublin, Dublin 2, Ireland \\ ${ }^{3}$ Laboratório de Nacional de Geologia e Energia, Rua da Amieira, 4465-965 S. Mamede Infesta, Portugal \\ ${ }^{4}$ Laboratório de Nacional de Geologia e Energia, Estrada Portela, Zambujal Alfragide, Ap.7586, \\ 2720-866 Amadora, Portugal \\ *Corresponding author (e-mail: pfernandes@ualg.pt)
}

\begin{abstract}
The Late Palaeozoic rocks of southern Portugal have a complex thermal history. Vitrinite reflectance determinations from 90 samples confirm that the organic maturity of Late Palaeozoic rocks in SW Portugal is very high, mainly corresponding to meta-anthracite coal rank. The optic fabric of vitrinite in oriented coal samples from the Brejeira Formation suggests maturation under simple, non-tectonic, burial conditions with peak temperatures being attained prior to Variscan deformation. The lack of any increase in vitrinite reflectance with depth through $c$. $1 \mathrm{~km}$ of section in borehole AC-1 is not consistent with conductive heat transfer and is interpreted as the result of late synorogenic to post-orogenic advective heating. This heating episode generated temperatures sufficiently high to produce levels of maturity corresponding to metaanthracite coal rank through much of the terrane now exposed, but not high enough to result in overprinting of the pre-deformation optic fabric of vitrinite in the thin coals. The slightly lower maturity of older, platformfacies rocks in the Aljezur-Bordeira area may reflect either deposition on a basement high followed by less burial than adjacent parts of the basin, or the area being the site of a sink for descending relatively cool fluids.
\end{abstract}

The South Portuguese Zone is one of the main geological units of the Variscan Iberian Massif (Fig. 1). Its faulted boundary against the Ossa Morena Zone in the north is marked by the Beja Acebuches Ophiolite and to the south it is overlain unconformably by Mesozoic sedimentary rocks of the Algarve Basin (Fig. 1). The Beja Acebuches Ophiolite is interpreted as a remnant of the Rheic Ocean that separated the Euramerican South Portuguese Zone from the Gondwanan Ossa Morena Zone (Oliveira 1990; Quesada et al. 1994; Oliveira \& Quesada 1998; Oliveira et al. 2006).

The South Portuguese Zone is divided into four 'domains' based on lithology, deformation style and age. The domains trend from NW-SE near the coast to east-west inland and generally young towards the SW. These domains are, from NE to SW, the Pulo do Lobo Antiform, the Pyrite Belt, the Baixo Altentejo Flysch Group and the Southwest Portugal Domain.

The Pulo do Lobo Formation crops out in the centre of the antiformal structure of the Pulo do Lobo Antiform. It consists of highly deformed phyllites and quartzites with small intercalations of amphibolites of mid-ocean ridge basalt (MORB)-type geochemical affinity. Detrital zircons from the quartzites suggest a maximum depositional age of $438 \mathrm{Ma}$ (Silurian) for the protolith of this formation (Braid et al. 2011). Flysch-type successions crop out on the northern and southern flanks of the antiform. These rocks are dated palynologically as Frasnian to late Famennian (Pereira et al. 2006, 2008). However, detrital zircons in the upper unit of the overlying flysch succession (the Santa Íria Formation) located on the northern limb of the Pulo do Lobo Antiform in Spain give a maximum depositional age of Tournaisian (347 $\pm 5.5 \mathrm{Ma}$, Braid et al. 2011), compared with the late Famennian age provided by palynomorphs for the same unit in Portugal (Pereira et al. 2006). This suggests eastward progradation of flysch deposition during late Famennian to Tournaisian time, although this requires further investigation.
Vitrinite reflectance (VR) of the organic matter from the flysch successions of the Pulo do Lobo Antiform indicates that metaanthracite coal rank was attained post-late Devonian (Pereira et al. 2006).

The Pyrite Belt succession consists of phyllites and quartzites of the Phyllite Quartzite Group overlain by volcanic rocks and sediments of the Volcano-Sedimentary Complex, which are often mineralized. Palynomorphs present in the uppermost beds of the Phyllite Quartzite Group indicate a Late Devonian age (Pereira et al. 2008). The Volcano-Sedimentary Complex is dated as Late Devonian to late Viséan based on palynomorphs and rare conodonts (Boogaard 1963, 1967; Oliveira \& Wagner Genthis 1983; Oliveira et al. 2004, 2005; Pereira et al. 2007, 2008). VR values from the Pyrite Belt in the São Domingos mine area range from 4.6 to $5.2 \%$ $R_{r}$, indicating a meta-anthracite coal rank (Pereira et al. 2006).

The Baixo Altentejo Flysch Group is a turbiditic sequence over $5 \mathrm{~km}$ thick that progrades southwards. The flysch sequence in the South Portuguese Zone is divided into three formations based on sedimentology and age. In ascending order these are the Mértola, Mira and Brejeira Formations. These units are dated by ammonoid faunas and palynomorphs as late Viséan, Serpukhovian to early Bashkirian, and late Bashkirian to late Moscovian respectively (Oliveira et al. 1979, 1985; Korn 1997; Pereira 1999; Pereira et al. 2007, 2008). The Baixo Altentejo Flysch Group represents the development of a foreland basin that formed as a result of the collision of the South Portuguese Zone and the Ossa Morena Zone, with associated tectonic stacking that propagated from NE to SW (Oliveira 1990; Silva et al. 1990; Pereira 1997, 1999). Reworked Cambrian to Early Devonian palynomorphs occur commonly in the Brejeira Formation (Pereira 1999), indicating a source area for these clastic sediments outside the South Portuguese Zone, as no rocks older than the Mid-Devonian crop out in the South Portuguese 